\title{
Corporate Social Responsibility: A Case Study Of TATA Group
}

\author{
Amit Kumar Srivastava ${ }^{1}$, Gayatri Negi ${ }^{2}$, Vipul Mishra ${ }^{3}$, Shraddha Pandey $^{4}$ \\ (1,4 Shri Ram Murti Smarak College of Engineering \& Technology, Bareilly, U P/India ) \\ $\left({ }^{2,3}\right.$ Career Degree College, kakori, Lucknow /U P / University of Lucknow / India)
}

\begin{abstract}
Starting from the times of barter system to today's modern era of plastic money, the mankind has trodden a remarkably long path. Undoubtedly "profitability" has always been the driving force and an undercurrent behind all this development; but as every coin has two facets; growing cut throat competition and business rivalries started taking heavy toll on the quality, transparency, environment and the society in general endangering the peaceful coexistence of business and society. The businesses houses started realizing that they would have to rise over and above the profitability and take care of all those associated with their survival in the society directly or indirectly. This realization resulted into the concept of Corporate Social Responsibility (CSR). This research paper moves around developing an understanding about the corporate social responsibility (CSR), delving into its concept and finding out its scope taking the case study of the TATA Group under Mr. Ratan Tata who has exemplified the sense of responsibility towards the upliftment of common masses and protection of the environment and development of the nation.
\end{abstract}

Keywords: Corporate citizenship, Corporate social responsibility, Employee, Productivity, Profitability, Society, Stakeholders.

\subsection{Literature Review}

\section{Introduction}

The concept of CSR originated in the 1950's in the USA but it became prevalent in early 1970s . At that time US had lots of social problems like poverty, unemployment and pollution. Consequently a huge fall in the prices of Dollar was witnessed. Corporate Social Responsibility became a matter of utmost importance for diverse groups demanding change in the business. During the 1980's to 2000, corporations recognized and started accepting a responsibility towards society. Corporate social responsibility (CSR) focuses on the wealth creation for the optimal benefit of all stakeholders - including shareholders, employees, customers, environment and society. The term stakeholder, means all those on whom an organization's performance and activities have some impact either directly or indirectly. This term was used to describe corporate owners beyond shareholders as a result of a book titled Strategic management: a stakeholder approach by R. Edward Freeman in the year 1984. ${ }^{1}$

According to Bowen, "CSR refers to the obligations of businessmen to pursue those policies to make those decisions or to follow those lines of relations which are desirable in terms of the objectives and values of our society. " 2 Frederick (1960) stated 'Social responsibility means that businessmen should oversee the operation of an economic system that fulfills the expectations of the people.' . ${ }^{3}$ Davis (1960) argued that social responsibility is a nebulous idea but should be seen in a managerial context. He asserted that some socially responsible business decisions can be justified by a long, complicated process of reasoning as having a good chance of bringing long-run economic gain to the firm, thus paying it back for its socially responsible outlook (p. 70). ${ }^{4}$ An ideal CSR has both ethical and philosophical dimensions, particularly in India where there exists a wide gap between sections of people in terms of income and standards as well as socio-economic status (Bajpai, $2001)^{5}$. Goyder(2003) argues: "Industry in the 20th century can no longer be regarded as a private arrangement for enriching shareholders. It has become a joint enterprise in which workers, management, consumers, the locality, govt. and trade union officials all play a part. If the system which we know by the name private enterprise is to continue, some way must be found to embrace many interests whom we go to make up industry in a common purpose." ). ${ }^{6}$ CSR implies some sort of commitment, through corporate policies and action. This operational view of CSR is reflected in a firm's social performance, which can be assessed by how a firm manages its societal relationships, its social impact and the outcomes of its CSR policies and actions (Wood, 1991). ${ }^{7}$

\subsection{Purpose}

To understand the concept and scope of corporate social responsibility and getting an insight in CSR practices in the light of the case study of the TATA Group. 
1.3 Objectives of the study

- To understand the concept of CSR

- To find out the scope of CSR

- To know how the Tata group has fulfilled its responsibility towards all stakeholders; what specific activities, programs and strategies it has set, devised and implemented for the same.

\subsection{Research Methodology}

Exhaustive literature survey regarding the topic and related concepts has been done. Secondary data inclusive of quantitative and qualitative data as well collected from various sources including books, research papers, newspapers, magazines, and websites is used for the purpose of study.

\section{Concentric Circle \& CSR}

In 1971, the Committee for Economic Development issued a report throwing light on different dimensions of responsibilities to be fulfilled by the corporate. The responsibilities of corporations are described consisting of three concentric circles.

(a) Inner Circle: Clear cut, basic responsibilities for the efficient execution of the economic function, products, jobs and economic growth.

(b) Intermediate Circle: Encompasses responsibility to exercise this economic function with a sensitive awareness of changing social values and priorities.

Eg. With respect to environmental conservation, hiring and relations with employees, expectation of customers for information, safety factors, etc.

(c) The Outer Circle: Newly emerging and still amorphous responsibilities that business should assume to become more broadly involved in actively improving the social environment.

\subsection{Responsibility towards itself}

\section{Classification of Social Responsibility}

It is the responsibility of each corporate entity run business and to work towards growth, expansion and stability and thus earn profits. If the corporation is to achieve social and economic ends, organizational efficiency should be boosted up.

\subsection{Responsibility towards Employees}

Employees are the most important part of an organization. Following are some of the responsibilities which a business entity has towards its employees-

- Timely payment

- Hygienic environment

- Good and impartial behavior

- Health care through yoga

- Recreational activities

- Encouraging them to take part in managerial decisions

\subsection{Responsibility towards shareholders}

It is the responsibility of corporate entity to safeguard the shareholders' investment and make efforts to provide a reasonable return on their investment.

\subsection{Responsibility towards state}

Out of the profit available, the state is entitled to a certain share as per the income tax laws. Utmost transparency has to be exerted regarding the profit \&loss account and the balance sheet.

\subsection{Responsibility towards consumers}

The Company should maintain high quality standards at reasonable prices. It should not resort to malpractices such as hoarding and blackmarketing.

\subsection{Responsibility towards environment}

It is the responsibility of the organization to contribute to the protection of environment. It should produce eco -friendly products. Moreover, industrial waste management must be taken care of.

\section{Social Responsibility Models}

There are some models which describe the evolution and scope of social orientation of companies. Notable ones include Carroll's model, ${ }^{\mathbf{8}}$ Halal's model ${ }^{9}$ and Ackerman's model ${ }^{10}$.

\section{(a) Carroll's Model}

Archie B. Carroll has defined CSR as the complete range of duties business has towards the society. He has proposed a 3-d conceptual model of corporate performance. According to Carroll, a firm has the following four categories of obligations of corporate performance.- 


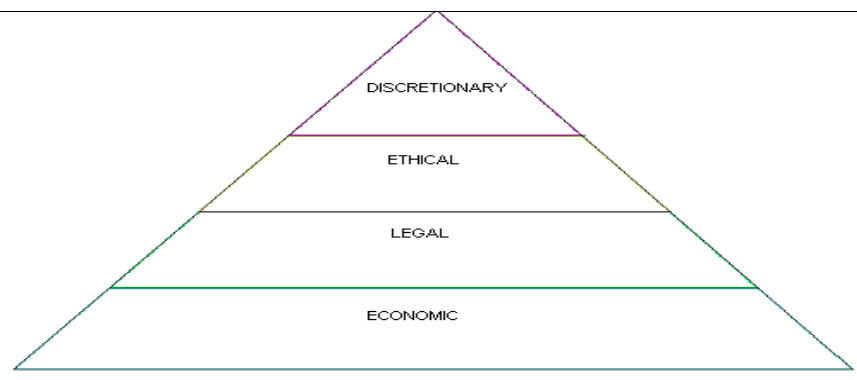

HIERARCHY OF RESPONSIBILITIES OF BUSINESS

- Economic: The firm being an economic entity, its primary responsibility is to satisfy economic needs of the society and generation of surplus for rewarding the investors and further expansion and diversification.

- Legal: The laws of the land and international laws of trade and commerce has to be followed and complied with.

- Ethical: Ethical responsibilities are norms which the society expects the business to observe like not resorting to hoarding and other malpractices.

- Discretionary: Discretionary responsibilities refer to the voluntary contribution of the business to the social cause like involvement in community development or other social projects pertaining to health and awareness of the masses.

\section{(b) Halal's model}

Halal's return on resource model of corporate performance recognizes the fact that the corporate social responsiveness is a quite difficult task as no corporate posture is value free. A firm can only attempt to form a workable coaliation among groups having diverse interests, engaged in creating value for distribution among members of coalition. The social issues may become conflicting beyond a certain level of economic activity. The coordination between economic and ethical decisions is necessary so that the future of the firm and shareholders may be safeguarded.

\section{(c)Ackerman's model}

This model defines CSR in three different phases

First phase - Top management recognizes social problem

Second phase - The company appoints staff specialists to look into the issue and find measures to tackle it Third phase - Implementation of the strategy derived by the specialists

\section{Corporate Social Responsibility as a Strategy}

CSR needs a proper and step by step implementation. Andrew (1980) ${ }^{\mathbf{1 1}}$ has developed an approach to the question of strategic choice. His four key questions suggest the approach that companies may follow in determining their level of CSR activity.

\section{Those four questions are following :}

a. Determining Organizational Competencies: what can we do?

b. Looking at Industry threats and opportunities: what might we do?

c. Examining the values of key implementers: what do we want to do?

d. Determining the social responsibility: what ought we to be doing? ${ }^{5}$

By finding out answers to these questions managerial decisions can be molded towards serving a strategic need. This means CSR in practical terms is an ongoing process, constantly monitoring the environment and inter and intra firm relationships. Burke Lee and Jeanne M. Logsdon (1996) ${ }^{\mathbf{1 2}}$ suggest that there are five dimensions of corporate strategy that are critical to the success of CSR process in terms of value creation by the firm. They are :

a. Centrality - CSR initiative activities should be close to the firm's mission and objectives.

b. Specificity- Strategic CSR initiatives should specifically benefit the firm. The firm should be able to capture the benefits of CSR initiatives.

c. Proactivity- CSR initiatives should focus on the dynamics of stakeholder expectations i.e. to capture the changes in socio-environmental, political and technological factors.

d. Voluntarism- CSR decisions should be discretionary and thus they should be taken up by the firm voluntarily.

e. Visibility- Strategic CSR initiative should build firm's image and add up to the goodwill by creating positive media attention. It can also mitigate negative image of the firm. 
The linkage between strategy and CSR is quite noticeable. As strategy implies choice there exists many opportunities to not only generate multiple options but also the choice between different modes of action, in a manner to attain corporate objectives more effectively. The question of trade-off rests between a body corporate defining a path of action that is governed by the need and desire for profits and social responsibility as well. A managerial decision- making grid can be thought of to help corporate generate multiple options.

Corporate Social Responsibility becomes strategic when it fetches substantial economic benefits to the firm, in particular, supporting the core business activities and thereby contributing to the accomplishment of its mission in the optimal manner enriching the firm and the society as well.

\subsection{Introduction}

\section{Tata Group \& CSR}

Ranging from steel, automobiles and software to consumer goods and telecommunications the Tata Group operates more than 80 companies. It has around 200,000 employees across India and thus has the pride to be nation's largest private employer. Mr. Ratan N. Tata has led the eminent Tata Group successfully. He was trained as an architect at New York's Cornell University but he chose to enter the family business .He assumed the Chairmanship of the Group in 1991. Named Business Man of the Year for Asia by Forbes in 2004, Mr. Ratan Tata serves on the board of the Ford Foundation and the program board of the Bill \& Melinda Gates Foundation's India AIDS initiative. Tata Group chairman Ratan Naval Tata has stepped down to pass on the entire responsibility to Cyrus Mistry. Under Tata, the group went through major organisational phases rationalisation, globalisation, and now innovation, as it attempts to reach a reported $\$ 500$ billion in revenues by 2020-21, roughly the size of what Walmart is today. ${ }^{\mathbf{1 3}}$

Approximately two third of the equity of the parent firm, Tata Sons Ltd., is held by philanthropic trusts endowed by Sir Dorabji Tata and Sir Ratan Tata, sons of Jamsetji Tata, the founder of todays Tata empire in the 1860s. Through these trusts, Tata Sons Ltd. utilizes on average between 8 to 14 percent of its net profit every year for various social causes. Even when economic conditions were adverse, as in the late 1990s, the financial commitment of the group towards social activities kept on increasing, from Rs 670 million in 1997-98 to Rs 1.36 billion in 1999-2000. In the fiscal year 2004 Tata Steel alone spent Rs 45 crore on social services. . ${ }^{14}$

Tata is accredited to initiate various labor welfare laws. For example- the establishment of Welfare Department was introduced in 1917 and enforced by law in 1948; Maternity Benefit was introduced in 1928 and enforced by law in 1946. A pioneer in several areas, the Tata group has got the credit of pioneering India's steel industry, civil aviation and starting the country's first power plant. It had the world's largest integrated tea operation. It is world's sixth largest manufacturer of watches (Titan).

\subsection{Recognition of CSR}

"In a free enterprise, the community is not just another stakeholder in business but is in fact the very purpose of its existence."

- Jamsetji Nusserwanji , Tata Founder, Tata Group.

"Corporate Social Responsibility should be in the DNA of every organization. Our processes should be aligned so as to benefit the society. If society prospers, so shall the organization..."

- Manoj Chakravarti, G M - Corporate Affairs \& Corporate Head - Social Responsibility, Titan Industries Limited in 2004.

Corporate Social Responsibility has always been taken care of by the Tata group. The founder Mr. Jamshedji Tata used to grant scholarships for further studies abroad in 1892 . He also supported Gandhiji's campaign for racial equality in South Africa. Tata group has given country its first science center and atomic research center. "The wealth gathered by Jamsetji Tata and his sons in half a century of industrial pioneering formed but a minute fraction of the amount by which they enriched the nation. Jamshed Irani, Director, Tata Sons Ltd, says, "The Tata credo is that 'give back to the people what you have earned from them'. So from the very inception, Jamshetji Tata and his family have been following this principle." (a statement on the Tata group's website www.tata.com) .

In July 2004, B. Muthuraman, Managing Director, Tata Steel Limited (TISCO) announced that in future TISCO would not deal with companies, which do not conform to the company's Corporate Social Responsibility (CSR) standards. Speaking at the annual general meeting of the Madras Chamber of Commerce and Industry, He stated, "We will not either buy from or sell to companies that do not measure up to Tata Steel's social responsibility standards." 


\subsection{Introducing Changes in the Company's Article and Rules for Sustaining CSR Clause No. 10 of Tata Group}

"A Tata Company shall be committed to be a good corporate citizen not only in compliance with all relevant laws and regulations but also by actively assisting in the improvement of the quality of life of the people in the communities in which it operates with the objective of making them self reliant. Such social responsibility would comprise, to initiate and support community initiatives in the field of community health and family welfare, water management, vocational training, education and literacy and encourage application of modern scientific and managerial techniques and expertise. This will be reviewed periodically in consonance with national and regional priorities. The company would also not treat these activities as optional ones but would strive to incorporate them as integral part of its business plan. The company would also encourage volunteering amongst its employees and help them to work in the communities. Tata companies are encouraged to develop social accounting systems and to carry out social audit of their operations."

Amendments were made to the Articles of Association of the major Tata group companies in the 1970s. Newly included was an article stating that the "company shall be mindful of its social and moral responsibilities to consumers, employees, shareholders, society and the local community. To institutionalize the CSR charter, a clause on this was put into the group's 'Code of Conduct.' This clause states that group companies had to actively assist in improving quality of life in the communities in which they operated. All the group companies were signatories to this code. CSR was included as one of the key business processes in TISCO. It was one of the eight key business processes identified by TISCO's management and considered critical to the success of the company.

\subsection{CSR Activities of Tata Companies \& Societies}

Through the following companies and societies Tata group keeps on heading towards the fulfillment of corporate social responsibility -

\subsection{Tata Steel}

Tata Steel has adopted the Corporate Citizenship Index, Tata Business Excellence Model and the Tata Index for Sustainable Development. Tata Steel spends 5-7 per cent of its profit after tax on several CSR initiatives.

\section{(a) Self-Help Groups (SHG's)}

Over 500 self-help groups are currently operating under various poverty alleviation programs; out of which over 200 are engaged in activities of income generation thorough micro enterprises. Women empowerment programs through Self-Help Groups have been extended to 700 villages. From the year 2003 to 2006 , the maternal and infant survival project had a coverage area of 42 villages in Gamharia block in Seraikela Kharsawa and a replication project was taken up in Rajnagar block. For providing portable water to rural communities 2,600 tube wells have been installed for the benefit of over four Lakh people.

\section{(b) Supports Social Welfare Organizations}

Tata Steel supports various social welfare organizations. They include;

$>$ Tata Steel Rural Development Society

$>$ Tribal Cultural Society

$>$ Tata Steel Foundation for Family Initiatives

$>$ National Association for the Blind

$>$ Shishu Niketan School of Hope

$>$ Centre for Hearing Impaired Children

$>$ Indian Red Cross Society, East Singhbhum

\section{(c) Healthcare Projects}

In its 100th year, the Tata Steel Centenary Project has just been announced. The healthcare projects of Tata Steel include facilitation of child education, immunization and childcare, plantation activities, creation of awareness of AIDS and other healthcare projects.

\section{(d) Economic Empowerment}

A program aiming at economic empowerment through improvised agriculture has been taken up in three backward tribal blocks in Jharkhand, Orissa and Chhattisgarh. An expenditure of Rs 100 crore has been estimated for the purpose and this program is expected to benefit 40,000 tribal living in over 400 villages in these three States. 


\section{(e)Assistance to government}

Tata Steel has hosted 12 Lifeline Expresses in association with the Ministry of Railways, Impact India Foundation and the Government of Jharkhand. It has served over 50,000 people. Five thousand people have got surgical facilities and over 1,000 people received aids and appliances. Over seven lac rural and another seven Lac urban population have been benefited by the CSR activities of Tata Steel.

The National Horticulture Mission program that has been taken up in collaboration with the Government of Jharkhand has benefited more than a thousand households. In collaboration with the Ministry of Non Conventional Energy and the Confederation of Indian Industry, focus is laid on renewable energy aiming at enhancing rural livelihood.

\subsubsection{Tata Motors :}

\section{(a) Pollution Control}

Tata Motors is the first Indian Company to introduce vehicles with Euro norms. Tata Motors' joint venture with Cummins Engine Company, USA, in 1992, was a major effort to introduce emission control technology in India. To make environment friendly engines it has taken the help of world-renowned engine consultants like Ricardo and AVL. It has manufactured CNG version of buses and also launched a CNG version of its passenger car, the Indica. Over the years, Tata Motors has also made investments in the establishment of an advanced emission-testing laboratory.

\section{(b) Restoring Ecological Balance}

Tata Motors has planted 80,000 trees in the works and the township and more than 2.4 million trees have been planted in Jamshedpur region. Over half a million trees have been planted in the Poona region. The company has directed all its suppliers to package their products in alternate material instead of wood. In Pune, the treated water is conserved in lakes attracting various species of birds from around the world.

\section{(c) Employment Generation}

Relatives the employees at Pune have been encouraged to make various industrial co-operatives engaged in productive activities like re-cycling of scrap wood into furniture, welding, steel scrap baling, battery cable assembly etc. The Tata Motors Grihini Social Welfare Society assists employees' women dependents; they make a variety of products, ranging from pickles to electrical cable harnesses etc ; thereby making them financially secure.

\section{(d) Economic Capital}

In Lucknow, two Societies - Samaj Vikas Kendra \& Jan Parivar Kalyan Santhan have been formed for rural development $\&$ for providing healthcare to the rural areas. These societies have made great efforts for health, education and women empowerment in rural areas.

\section{(e) Human Capital}

Tata motors has introduced many scholarship programs for the higher education of the children. Through a scholarship program Vidyadhanam, the company supports 211 students. Out of these students 132 students are from the marginalized sections of the society. These students get books, copies and other study materials. They also undergo different kinds of workshops, creative $\&$ outdoor sessions and residential camps as well.

The company has entered into Public-Private Partnership (PPP) for upgrading 10 Industrial Technical Institutes (ITI) across the country.

\section{(f) Natural Capital}

On the World Environment Day, Tata Motors has launched a tree plantation drive across India and countries in the SAARC region, Middle East Russia and Africa. As many as 25,000 trees were planted on the day. Apart from this more than 100,000 saplings were planted throughout the monsoon. ${ }^{15}$

\subsubsection{Tata Chemicals Ltd (TCL)}

Tata Chemicals is making an effort for sustainability. Sustainability for the group means honesty and transparency towards stakeholders, environmental protection, generating economic value, promoting human rights and creating social capital. Tata Chemicals supports the UN Global Compact and is committed to reporting its sustainability performance in accordance with GRI (Global Reporting Initiatives) guidelines. Its main operations for environment protection include optimal use of resource, finding and/or generating 
alternative sources of fuel and raw materials, and maximizing reuse and recycling. All in all they have the policy of 'avoid, reduce and reuse'. The company runs a rural development program at Okhamandal and Babrala.

Tata Chemicals Limited was one of the first organizations to hold an Impact camp, which was held at Mithapur in the year 1982, providing eye care to hundreds of patients at the Mithapur Hospital. Tata Chemicals Limited was also the first organization to run world's first hospital on wheels - the Life Line Express, through Jamnagar district for the first time between November 21, 2004 and December 21, 2004. ${ }^{\mathbf{1 6}}$

\subsubsection{Tata Tea}

Tata Tea has been working hard since the 1980s to fulfill the needs of specially-abled people. It has set up the Srishti Welfare Centre at Munnar, Kerala; its various programs provide education, training and rehabilitation of children and young adults with special needs.

Srishti has four projects:

a. The DARE School

b. The DARE strawberry preserve unit

c. Athulya

d. Aranya.

Tata Tea's welfare officers help identify and encourage relatives or children of employees who are handicapped to join the Welfare Centre for special education and rehabilitation.

\section{a.The DARE}

It provides the students with training in basic academics, self-help skills and skills like gardening, cooking, weaving etc. Children are taught to paint and some of the paintings are printed and sold as greeting cards. The sales proceeds of which are used back into the units.

b.The DARE strawberry

It preserves unit trains youngsters to make natural strawberry preserve. The trainees are paid for the work; they receive social cover, free medical aid and other benefits.

\section{c.Athulya}

It has two units -

(i) A vocational training center that imparts training in stationery-making

(ii) A handmade paper-making unit which trains physically challenged persons in the art of making recycled paper

\section{d.Aranya}

This project was started to nurture the lives of the disabled and also to revive the ancient art of natural dye. Individuals are given training in various natural dyeing techniques including block printing, tie and dye, batik work, etc. Their products are sold in and outside the country . ${ }^{17}$

Tata Tea's Jaago Re! Campaign exemplifies the Social-Cause Marketing Initiatives .

\subsubsection{Titan}

Corporate social responsibility is a basic element of TITAN Group's governing objective and one of its corporate values. In its corporate philosophy CSR is defined as doing less harm and more good by adopting the following practices :

- Respecting and supporting local communities

- Caring for the employees

- $\quad$ Being an active member of society

- Committed to sustainable development

- $\quad$ Putting safety(at work) first

Titan has employed 169 disabled people in blue collar workforce at Hosur.

\subsubsection{TISCO}

TISCO was awarded The Energy Research Institute (TERI) award for Corporate Social Responsibility (CSR) for the fiscal year 2002-03 in recognition of its corporate citizenship and sustainability initiatives. As the only Indian company trying to put into practice the Global Compact principles on human rights, labor and environment, TISCO was also conferred the Global Business Coalition Award in 2003 for its efforts in spreading awareness about HIV/AIDS.

\subsubsection{TELCO}

TELCO, Puna has started community development activities for the benefit of TELCO families and local residents in 1973 with the following objectives: 
1. To create social awareness in all the employees and their families, to promote congenial mutual relations amongst them, to improve personal and environmental hygiene and health

2. To help the families of employees develop better living standards by organizing extension education programs, training in various trades/skills and providing opportunities to earn additional income.

TELCO is fighting against Leprosy at Jamshedpur.

\subsubsection{Tata Consultancy Services (TCS)}

TCS aims at the Tata group's philosophy of building strong sustainable businesses community . The elements that make for strong corporate sustainability at TCS include the following: A fair, transparent corporate governance, a strong strategy for long-term growth ,Best-in-class HR processes, initiatives for community betterment and welfare.

In 2010-11, TCS supported its local communities in the United States: supported the victims of the 2010 Chilean earthquake, conducted IT educational programs for high school students in Cincinnati, raised support and awareness for diabetes prevention through a series of marathon sponsorships

Tata Consultancy Services runs an adult literacy program. Indian government launched Saakshar Bharat, an adult education programe in 2009 and the programe will now go online via TCS' partnership. The scheme, aimed at female literacy aims to make literate 70 million people, of which at least 85 percent are women literate and the program has already been rolled out in 167 districts across 19 states. ${ }^{18}$

\subsubsection{Tata Archery Academy}

The Tata Archery Academy was established in Jamshedpur in 1996 . The academy has all the training facilities like highly efficient coaches, archery grounds, equipment from India and abroad. It also provides hostel and multi gymnasium facilities for its cadets.

After a rigorous selection process being carried all over India, the Academy selects boys and girls between the age group of 13 to 18 years for the four years course and it provides the training during which the cadets are also imparted with formal education. Some of the major championships where the of the Tata Archery Academy cadets have participated and have won several medals are Junior world Archery Championship, Senior World Archery Championship, Asian Archery Championship, Commonwealth Games and Asian Games.

\subsubsection{TQMS}

Tata Quality Management Services (TQMS - a division of Tata Sons) had been entrusted with the task of institutionalizing the Tata Business Excellence Model (TBEM). The TBEM provides each company with a wide outline to help it improve business performance and attain higher levels of efficiency and productivity. It aims to facilitate the understanding of business dynamics and organizational learning. TBEM is a 'customizedto-Tata' adaptation of the globally renowned Malcolm Baldrige model. TBEM model focuses on seven core aspects of operations: leadership, strategic planning, customer and market focus, measurement, analysis and knowledge management, human resource focus, process management and business results. Performance is measured in absolute points; companies have to achieve a minimum of 500 points (out of 1,000) within four years of signing the BEBP agreement.. TQMS helps Tata companies use the model to gain insights on their business strengths and opportunities for improvement. This is managed through an annual process of assessment and assurance. The model, through its regular and calibrated updates, is used by Tata companies to stay in step with the ever-changing business environment.

\section{TBEM based performance excellence goals:}

Basically TBEM Criteria is designed to help organizations use an integrated approach to performance management that results in delivery of ever-improving value to customers and stakeholders, contributing to organizational sustainability improvement of overall organizational effectiveness organizational and personal learning .

\subsubsection{TCSRD}

Tata Chemicals Limited (TCL) set up the Tata Chemicals Society for Rural Development (TCSRD) in 1980 to promote its social objectives for the communities in and around Mithapur, where its facility is located. This service was further extended to the communities in and around its Babrala and Haldia facilities.

Through Tata Chemicals Society for Rural Development (TCSRD) Tata Chemicals works to improve the quality of life of the people and communities. It also aims at supporting sustainable development, which is the central theme of the company's corporate philosophy. It works to protect and nurture the rural populations in and around TCL's facilities, and assists people in attaining self-sufficiency in natural resource management, livelihood support. It also aims at the building of health and education infrastructure i.e. schools and hospitals, maternity centers etc. 
The initiatives that TCSRD is involved in include:

a) Agricultural development

b) Animal husbandry

c) Watershed development

d) Education

e) Rural energy

f) Women's programs

g) Relief work

\subsubsection{Tata Relief Committee}

Tata Relief Committee (TRC) works to provide relief at disaster affected areas. During natural calamities there are two phases of assistance - (a) relief measures and (b) rehabilitation program.

After the Gujarat earthquake the group built 200 schools in two years and they rendered help during the Orissa floods when people lost cattles. Even after the Tsunami disaster members of TRC immediately reached the places and supplied the things required.

\subsubsection{Tata Council for Community Initiatives (TCCI)}

TCCI was established in 1994 . TCCI's mission states: "We will work together to be, and to be seen as, a group which strives to serve our communities and the society at large". TCCI is also involved in assisting Tata companies maintain sustainability reporting the guidelines of Global Reporting Initiative (GRI). It is the focal point for the UN Global Compact in India, which has 42 Tata companies as signatories, the highest in the world from a single business group.

In collaboration with the United Nations Development Programme (India), TCCI has crafted the Tata Index for Sustainable Human Development, aiming at directing, measuring and enhancing the community work that Tata enterprises is undertaking for the upliftment and welfare of the people.

\subsection{Tata Corporate Sustainability Policy}

"No success or achievement in material terms is worthwhile unless it serves the needs or interests of the country and its people.

- J R D Tata

The corporate policy of the group encompasses the sustainable development of all the stakeholders. The major points included in the corporate policy are following :

- Demonstrate responsibility and sensitivity to biodiversity and the environment

- Comply with rules and regulations relating to environment

- constantly upgrade technology and apply state-of-the-art processes and practices with institutional arrangements that will combat larger issues like climate change and global warming

- Create sustainable livelihoods and build community through social program pertaining to health, education, empowerment of women and youth, employee volunteering,

- Find ways to enhance economic human, social and natural capital for bringing and maintaining a balance among business, society and environment.

\subsection{Dedications to the Nation at a Glance}

\subsubsection{Tata Health Infrastructure}

- Tata main hospital at Jamshedpur

- ICU in Joda and Balangpur

- CHC in Bari and Kuhika

- Hospitals in Gobarghati,sukinda, joda, belpahar, belipada and bamnipal

- "Lifeline Express"- the hospital on wheels

- Mobile health clinics

- Centre for hearing impaired children

\subsubsection{Tata Educational Infrastructure}

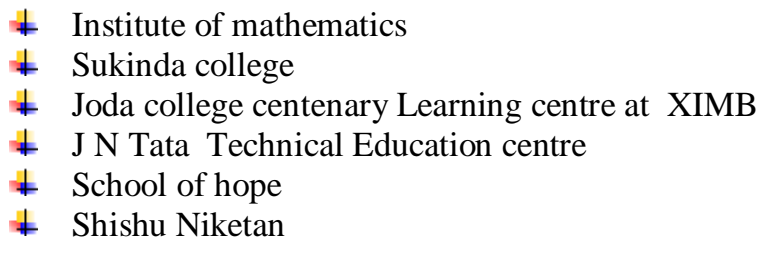




\subsubsection{Tata Sports Infrastructure}

- Tata athletics academy

- Tata archery academy

- Tata Football academy

- Tata steel adventure foundation

- Sports feeder centres

- Stadium at keonjhar

6.6.4 Preservation of culture \& Heritage

- Contribution to setting up national Center for performing arts Mumbai

- Tribal cultural centers showcases legacy of nine tribes Jharkhand and Orissa

- Gramshree mela activities

\section{Conclusion}

For bringing back and maintaining the general balance in the economic and social arena it is evident to think deeply and act wisely about CSR. Every business house owe some responsibility towards the society, nation and world in general which provide it with all human, material and natural resources. Considering the long run growth and sustainable development following the norms of CSR, devising new policies and effective implementation is inevitable to bring and sustain a balance between corporate world and society, present generation and upcoming generation, man and nature .

As far as the Tata group is concerned, it has gone a long way in fulfilling its duty and responsibility towards the society and the nation. It has reached the masses to elevate their lives, to nurture their dreams and to hone their skills justifying the statement of the founder "We do not claim to be more unselfish, more generous and more philanthropic than other people. But we think we started on sound and straightforward business principles, considering the interests of the shareholder, our own, and the health and welfare of the employees, the sure foundation of our prosperity".

\subsection{Findings}

- As business is an integral part of the social system it has to care for varied needs of the society

- Business which is resourceful has a special responsibility to the society.

- Social involvement of business would enhance a harmonious and healthy relationship between the society and business seeking mutual benefit for the both.

- Social involvement may create a better public image and goodwill for the company which further becomes instrumental in attracting customers, efficient personnel and investors.

\subsection{Limitations}

While preparing this research paper Legal aspects like corporate governance, labor and employee welfare related laws have not been undertaken.

\subsection{Significance of the study}

\section{A. To the Policy Makers}

- This study encourages Private Public Partnership (PPP) for CSR promotion encompassing infrastructure, pollution, child labor, labor productivity \& morale.

- It may become helpful to make the policy makers at political and corporate level as well consider CSR an investment and not an expense as it can become instrumental in increasing goodwill and corporate image.

\section{B. To the Society}

- Development of infrastructure i.e. parks, water purification, education etc.

- Environment protection

- Uplifting of the rural populace

- $\quad$ Bringing the tribes into the mainstream of the country

\section{To the Economy as a whole}

- Increase in the growth rate

- Strategic CSR at political and corporate level can make the country a better investment destination

- Cumulative results may improve Human Development Index (H.D.I.) of the country. 


\subsection{Recommendations}

- The concept of private-public partnership (PPP) should be applied in the effective implementation of CSR i.e. government and business houses should act in collaboration for the cause.

- The Human Resource department (at the political and private level both) should be entrusted with the responsibility of measuring and evaluating in CSR activities . It can be done in two forms -

(a) direct results, such as, economic and financial savings

(b) indirect results like increase in employee satisfaction, less absenteeism, less employee turnover evaluated by staff surveys

- Periodic review of the CSR activities should be conducted by every business entity so as to identify the pitfalls and the areas left out.

- Innovation should essentially be a matter of concern; be it searching the untouched areas and scope of CSR or the formulation of CSR strategy or the implementation thereof.

- NGOs should be encouraged to act in collaboration for the CSR activities under different schemes and projects as they play a crucial role in the upliftment of the masses.

\section{Books}

[1] Freeman, R.E. Strategic Management: A Stakeholder Approach ( Pitman Publishing: Marshfield, MA ,1984)

[2] Bowen, H. R, Social responsibilities of the businessman (New York: Harper \& Row, 1953)

[3] Frederick, W.C., The growing concern over business responsibility (California Management Review, Vol.2, 1960) pp. 54-61

[4] Davis, Keith, Can Business Afford to Ignore Social Responsibilities? (California Management Review, Spring, 1960)

[6] Mark Goyder, Redefining CSR: From the Rhetoric of Accountability to the Reality of Earning Trust (Tomorrow's Company, 2003)

[7] Wood, D.J., Towards improving corporate social performance (Business Horizons, Vol. 34 No. 4, World Business Council for Sustainable Development 1991) pp. 66-73

[9] Halal ,W. E, Corporate community:A theory of the firm uniting profitability \&responsibility,strategy \&leadership.(vol 28. No 2. , 2000), pp10-16

[10] Ackerman, R. W., \& Bauer, R. A. ,Corporate social responsiveness. (Reston,VA:Reston. 1976)

[11] Andrews, Kenneth R, The Concept of Corporate Strategy (Homewood, IL: Dow Jones-Irwin, 1971)

[12] Burke Lee and Jeanne M. Logsdon, Corporate Social Responsibility Pays Off [Long Range Planning, Volume 29, Issue 4, (August), 1996] pp. 437-596

\section{Webliography}

[5] Bajpai, G.N., Corporate Social Responsibility in India and Europe: Cross Cultural Perspective, 2001, http://www.ficci.com

[8] Archie B. Carrol, The pyramid of Corporate Social Responsibility: Toward the moral management of organizational stakeholders, from Business Horizons, July-August 1991,The Faundation for the School of Business at Indiana University http://www.cba.ua.edu/ aturner/MGT341/MGT341\%20Readings/Pyramid.pdf [6]

[13] Innovation is a Journey with a Compass, may21,2012 www.financialexpress.com

[14] Forerunners in corporate social responsibility, March 16, 2005 |The Indian Express, www.tata.com

[15] Tata Motors : Corporate Social Responsibility Annual Report 2009-10 www.tatamotors.com/sustainability/CSR-10/content.php

[16] www.tatachemicals.com , 22 Jan 2008

[17] www.tata.com/0_our_commitment/community_initiatives/tcci.html

[18] www.pluggd.in/india 